\title{
Profil Pasien Pneumonia Komunitas di Bagian Anak RSUP DR. M. Djamil Padang Sumatera Barat
}

\author{
Osharinanda Monita ${ }^{1}$, Finny Fitry Yani $^{2}$, Yuniar Lestari ${ }^{3}$
}

\begin{abstract}
Abstrak
Pneumonia adalah proses inflamasi pada parenkim paru dan merupakan penyebab utama morbiditas dan mortalitas anak berusia di bawah lima tahun, terutama di negara berkembang. Prevalensi kejadian pneumonia komunitas pada anak di Sumatera Barat cukup tinggi. Tujuan penelitian ini yaitu untuk mengetahui gambaran pasien pneumonia komunitas di Bagian Anak RSUP Dr. M. Djamil Padang tahun 2010-2012. Penelitian ini bersifat deskriptif dengan menggunakan data rekam medik anak yang dirawat dengan diagnosis utama pneumonia periode 1 Januari 2010 sampai 31 Desember 2012 dan diperoleh jumlah sampel sebanyak 178 orang anak. Hasil penelitian yang didapatkan yaitu pneumonia komunitas pada anak banyak terdapat pada anak laki-laki 55,6\%, terutama pada kelompok usia $2-<12$ bulan $60 \%$ dengan status gizi anak yang kurang $62 \%$ dan status imunisasi masih belum lengkap $34,8 \%$. Keluhan utama anak dengan pneumonia yaitu sesak napas $97,8 \%$ dan gejala klinis yang ditemukan yaitu demam $92,7 \%$ dengan suhu rata-rata $37.6 \mathrm{C}$, batuk 92,1\%, takipneu rata-rata laju napas $66 \mathrm{kali} / \mathrm{menit}$ pada kelompok usia < 2bulan, takikardi rata-rata denyut nadi 124 kali/menit pada kelompok usia $>48-72$ bulan, disertai nafas cuping hidung $92,7 \%$, retraksi dinding dada $86 \%$, ronkhi $91,6 \%$ dan wheezing $14,6 \%$. Pada pemeriksaan penunjang didapatkan jumlah leukosit dalam batas normal 63\% dan gambaran foto rontgen thoraks berupa infiltrat $96,6 \%$. Penyakit yang sering menyertai pneumonia pada anak yaitu anemia 30,9\% dan komplikasi yang terjadi berupa gangguan keseimbangan asam-basa 48,3\%. Lama rawatan paling banyak 5-10 hari dengan outcome perbaikan $56,7 \%$. Tingginya insiden pneumonia anak di RSUP DR. M. Djamil dipengaruhi oleh beberapa faktor, diantaranya yaitu status gizi kurang, status imunisasi yang belum lengkap, serta faktor lingkungan tempat tinggal anak.
\end{abstract}

Kata kunci: profil, pneumonia komunitas, anak

\begin{abstract}
Pneumonia is infection or inflammation of the lung and it is a major cause of morbidity and mortality in children aged under five years, especially in developing countries. Prevalence of CAP in children at West Sumatra is quite high. The objective of the study was to report the profile of CAP in pediatric ward of DR. M. Djamil Hospital Padang in 2010-2012. This research was a descriptive study using medical records of children with primary diagnosis of CAP in the period of January 1, 2010 until December 31, 2012. During the study period, 178 patients were diagnosed as CAP, 55.6\% found in boys, especially in the age group 2 - <12 months $43.8 \%$ with the poor nutritional status $62 \%$ and $34.8 \%$ have incomplete immunization status. The chief complaint of children with pneumonia are shortness of breath $97.8 \%$, and clinical symptoms such as fever found $92.7 \%$ with an average temperature of $37.6 \mathrm{C}$, cough $92.1 \%$, takipneu average respiratory rate 66 breaths/min in the age group <2 months, tachycardia average pulse rate 124 beats/min in the age group >48-72 months, with nasal flaring $92.7 \%$, chest wall indrawing $86 \%$, rhonchi $91.6 \%$ and wheezing $14.6 \%$. The laboratory test showed leucocyte $63 \%$ within normal limits and infiltrate found in 96,6\% chest radiograph. Accompanying diseases that often in children with pneumonia are anemic $30.9 \%$ and complications that occur is acid-base balance disorders 48,3\%. The hospital length of stay for children is 5-10 days and $56.7 \%$ children had improvement outcomes. The high incidence of CAP in children at DR. M. Djamil hospital influenced by several factors, such as malnutrition status, incomplete immunization.
\end{abstract}

Keywords: profile, community-acquired pneumonia, children 
Affiliasi penulis : 1. Pendidikan Dokter FK UNAND (Fakultas Kedokteran Universitas Andalas Padang), 2. Bagian IImu Kesehatan Anak FK UNAND/RSUP Dr. M. Djamil Padang, 3. Bagian IImu Kesehatan Masyarakat FK UNAND

Korespondensi :Osharinanda Monita,E-mail:

osharinanda@gmail.com, Telp: 083186420007

\section{PENDAHULUAN}

Pneumonia adalah peradangan yang mengenai parenkim paru, yang disebabkan oleh mikroorganisme, aspirasi dari cairan lambung, benda asing, hidrokarbon, bahan-bahan lipoid dan reaksi hipersensitivitas. $^{1,2}$ Pneumonia yang didapat di masyarakat disebut pneumonia komunitas (Community-Acquired Pneumonia). ${ }^{3} \quad$ Pneumonia komunitas merupakan masalah kesehatan yang menyebabkan angka kematian tinggi di dunia dan menjadi salah satu dari 5 penyebab utama kematian pada anak usia di bawah 5 tahun di negara berkembang, dengan jumlah kematian sekitar 3 juta kematian/tahun. ${ }^{3,4}$ Tingkat kematian anak dibawah usia lima tahun di sebagian besar negara berkembang berkisar 60-100 per 1000 kelahiran hidup, seperlima dari kematian ini disebabkan oleh pneumonia. ${ }^{5}$ Pneumonia yang terjadi pada balita akan memberikan gambaran klinik yang lebih jelek daripada orang dewasa karena pada balita sistem pertahanan tubuh yang dimiliki relatif rendah. Bayi dan anak kecil lebih rentan terhadap penyakit ini karena respon imunitas mereka masih belum berkembang dengan baik. ${ }^{6}$

Terdapat berbagai faktor risiko yang menyebabkan tingginya angka mortalitas pneumonia pada anak balita di negara berkembang. Faktor risiko tersebut yaitu umur, jenis kelamin, berat badan lahir, imunisasi yang tidak lengkap, tidak mendapatkan ASI yang adekuat, status gizi kurang, defisiensi vitamin $A$, tingginya prevalens kolonisasi bakteri patogen di nasofaring, orang dengan immunocompromised, tingginya pajanan terhadap polusi udara, kepadatan hunia, dan ventilasi udara rumah yang tidak baik. ${ }^{5-13}$

Angka kejadian pneumonia di Sumatera Barat setiap tahunnya meningkat, terbukti pada tahun 2012 diperkirakan terdapat 48.591 anak menderita pneumonia yang didapat dari komunitas dan Kota Padang merupakan daerah yang memiliki angka kejadian tertinggi yaitu sebesar 8.670 kasus. $^{5}$

\section{METODE}

Penelitian ini merupakan penelitian deskriptif dengan mengambil data rekam medik dari pasien pneumonia anak yang terdaftar di Bagian Anak RSUP DR.M.Djamil Padang periode 1 Januari 2010 - 31 Desember 2012. Populasi penelitian adalah semua anak penderita pneumonia komunitas yang dirawat di Bagian Anak RSUP DR. M. Djamil Padang periode 1 Januari 2010 - 31 Desember 2012. Sampel penelitian ini adalah seluruh populasi yang termasuk dalam kriteria inklusi yaitu anak usia $>1$ bulan. Kriteria eksklusi adalah data pada rekam medik yang tidak lengkap.Pengolahan data menggunakan program komputer dan hasil disajikan dalam bentuk tabel dan narasi.

\section{HASIL DAN PEMBAHASAN}

Penelitian yang telah dilakukan di RSUP DR. M. Djamil Padang selama periode 1 Januari 2010 - 31 Desember 2012 mendapatkan 352 kasus pneumonia komunitas pada anak. Dari 352 kasus tersebut, didapatkan 178 kasus yang memiliki data sesuai dengan kriteria inklusi.Selanjutnya 178 kasus tersebut dijadikan sebagai subjek penelitian. Berikut adalah hasil yang diperoleh : 
Tabel 1. Karakteristik Dasar Pasien Pneumonia Anak

\begin{tabular}{lcc}
\hline \multicolumn{1}{c}{ Karakteristik dasar } & $\mathbf{n}$ & $\%$ \\
\hline Jenis Kelamin & & \\
Laki-laki & 99 & 55,6 \\
Perempuan & 21 & 44,4 \\
\hline Usia & 11,8 \\
$1-<2$ bulan & 78 & 43,8 \\
$2-<12$ bulan & 63 & 35,4 \\
$12-60$ bulan & 16 & 9 \\
$>60$ bulan & 127 & 62 \\
\hline Status Gizi & 48 & 23,4 \\
Gizi Kurang & 3 & 1,5 \\
Gizi Baik & & \\
Gizi Lebih & 62 & 34,8 \\
\hline Status Imunisasi & 61 & 34,3 \\
Belum Lengkap & 55 & 30,9 \\
Tidak Lengkap & \\
Lengkap &
\end{tabular}

Tabel 1 memperlihatkan bahwa persentase pasien anak laki-laki lebih banyak dari pada anak perempuan dengan perbandingan 1,25: 1. Pada penelitian Nurjannah yang dilakukan di RSUD DR. Zainal Abidin Banda Aceh didapatkan kasus pneumonia pada anak sebanyak 144 kasus selama tahun 2008 hingga 2009 dengan persentasi pasien pneumonia anak laki-laki lebih tinggi dari pada pneumonia pada anak perempuan yaitu $59,3 \%$. $^{15}$ Berbeda halnya dengan penelitian yang dilakukan oleh Sarika Mauli di wilayah kerja puskesmas Kota Sigli Kabupaten Pidie, Banda Aceh pada tahun 2013, pneumonia lebih banyak ditemukan pada anak perempuan dibandingkan anak laki-laki dengan perbandingan 1,3:1. ${ }^{16} \mathrm{Hal}$ ini bisa terjadi karena pengaruh faktor ekstrinsik lain yang berperan dalam kejadian pneumonia di daerah tersebut seperti lingkungan tempat tinggal anak atau status gizi yang kurang dan status imunisasi yang tidak lengkap. Mekanisme mengapa pneumonia lebih banyak diderita anak laki-laki belum diketahui. ${ }^{17}$ Dari hasil penelitian Hartati ditemukan bahwa tidak ada hubungan bermakna antara jenis kelamin dengan kejadian pneumonia pada anak. ${ }^{8}$

Kelompok usia terbanyak menderita pneumonia dalam penelitian ini yaitu $2-<12$ bulan sebesar 43,8\%. Hasil ini hampir sama dengan penelitian yang dilakukan oleh Febianne Eldrian di Bagian Anak RSUP DR. M. Djamil Padang pada tahun
2001-2004 yang mendapatkan kelompok usia terbanyak pada usia $<1$ tahun sebesar $46,8 \%{ }^{18}$ Penelitian Yudhi Kurniawan di RSUP Nusa Tenggara Barat juga menemukan kelompok usia 0-1 tahun merupakan kelompok usia yang paling tinggi insiden pneumonia yaitu sebesar $48,6 \%{ }^{19}$ Anak kelompok usia kurang dari satu tahun lebih rentan terhadap penyakit pneumonia karena imunitas yang belum sempurna, saluran pernapasan yang cukup sempit serta tingginya prevalensi kolonisasi bakteri patogen di nasofaring. Penelitian di Lombok memperlihatkan pada usap tenggorok anak usia kurang dari 2 tahun ditemukan S.pneumoniae $48 \%$, yang mana bakteri ini merupakan penyebab pneumonia pada anak. ${ }^{6,10}$

Pada penelitian ini didapatkan anak dengan gizi kurang lebih banyak terkena pneumonia sebesar $62 \%$.Penelitian lain menjelaskan kejadian pneumonia pada anak dengan gizi kurang berpeluang sebesar 6,25 kali dibandingkan dengan anak yang berstatus gizi baik. ${ }^{8}$ Sistem imunitas pada bayi atau balita belum terbentuk sempurna, maka dari itu bayi akan lebih mudah terkena infeksi bila tidak mendapatkan asupan gizi yang cukup. Banyak peneliti menemukan hubungan yang signifikan antara malnutrisi dengan kematian anak yang menderita pneumonia. Di negara berpenghasilan rendah dan sedang, kekurangan berat badan merupakan faktor risiko pneumonia. ${ }^{19} \mathrm{Di}$ Sumatera Barat masih banyak anak balita yang memiliki gizi buruk dimana prevalensi gizi buruk sekitar $17,6 \%$ dan gizi kurang sekitar $14 \% .^{20}$

Pneumonia pada anak paling banyak ditemukan pada anak dengan status imunisasi yang belum lengkap.Anak yang belum mendapatkan imunisasi lebih rentan terkena pneumonia. Imunisasi merupakan cara pencegahan terkena penyakit menular karena kekebalan tubuh anak belum terbentuk sempurna. Imunisasi yang berhubungan dengan kejadian penyakit pneumonia adalah imunisasi pertusis dalam DPT, campak, Haemophilus influenza, dan pneumokokus. ${ }^{21}$ Pertusis dalam kondisi berat dapat menyebabkan pneumonia.Selain pertusis, campak juga mempunyai komplikasi pneumonia yang bahkan dapat mengakibatkan kematian, terutama pada anak kurang gizi dan anak dengan gangguan sistem imun.Komplikasi pneumonia yang timbul pada anak yang sakit pertusis dan campak biasanya 
berat.Dengan menurunkan kejadian penyakit pertusis dan campak pada balita melalui pemberian vaksinasi, kematian anak akibat pneumonia dapat diminimalkan. $^{22}$ Pada penelitian ini ditemukan sebanyak $34,8 \%$ anak dengan status imunisasi yang belum lengkap, 34,3\% anak dengan status imunisasi tidak lengkap dan 30,9\% anak dengan status imunisasi yang lengkap. Status imunisasi yang tidak lengkap merupakan faktor risiko kejadian pneumonia pada anak umur 6-59 bulan, dengan risiko menderita pneumonia 2,39 kali lebih besar daripada anak dengan status imunisasi yang lengkap. ${ }^{23}$

Tabel 2. Keluhan Utama Pasien Pneumonia Anak

\begin{tabular}{lcc}
\hline \multicolumn{1}{c}{ Keluhan Utama } & $\mathbf{n}$ & $\%$ \\
\hline Sesak Napas & 174 & 97,8 \\
Terminum benda asing & 1 & 0,6 \\
Demam & 1 & 0,6 \\
Kejang & 1 & 0,6 \\
Sianosis & 1 & 0,6 \\
\hline
\end{tabular}

Tabel 2 memaparkan keluhan utama pada anak dengan pneumonia. Keluhan utama yang ditemukan pada anak dengan pneumonia yaitu sesak napas sebanyak 174 (97,8\%) anak. Pada penelitian ini sesak napas dibagi menjadi dua kategori, anak datang dengan lama onset sesak napas 24 jam pertama dan sesak napas lebih dari 24 jam, dengan tujuan agar bisa mengetahui outcome anak dengan pneumonia serta ketanggapan orangtua dalam penanganan awal pneumonia. Dari $97,8 \%$ anak yang datang dengan sesak napas, $61,5 \%$ diantaranya datang dengan onset kurang dari 24 jam dan 38,5\% datang dengan onset sesak napas lebih dari 24 jam. Anak yang terlambat datang mencari pengobatan di tempat fasilitas kesehatan lebih dari 3 hari akan menunjukkan gejala pneumonia berat dan meningkatkan risiko kematian pada anak. ${ }^{24}$

Berdasarkan hasil penelitian didapatkan $55,1 \%$ anak yang datang dengan onset sesak napas kurang dari 24 jam pulang dengan perbaikan dan $59,7 \%$ anak yang datang dengan onset sesak napas lebih dari 24 jam pulang dengan perbaikan. Hal ini belum membuktikan anak yang cepat mencari pengobatan di tempat fasilitas kesehatan mendapatkan hasil terapi yang lebih baik dibandingkan anak yang datang lebih lambat.Keberhasilan terapi pada pasien pneumonia anak juga bergantung pada penyakit penyerta serta komplikasi yang dapat muncul selama anak dirawat.Namun penelitian terkait tentang waktu anak datang ke rumah sakit dengan keberhasilan terapi belum ditemukan.

Tabel 3. Gejala Klinis Pneumonia pada Anak

\begin{tabular}{lcc}
\hline \multicolumn{1}{c}{ Gejala Klinis } & $\mathbf{n}$ & $\%$ \\
\hline Demam & 165 & 92,7 \\
Batuk & 164 & 92,1 \\
Muntah & 70 & 39,3 \\
Pilek & 63 & 35,4 \\
Berak-berak encer & 22 & 12,4 \\
Sianosis & 6 & 3,4 \\
Kejang & 5 & 2,8 \\
Tidak mau menyusu & 4 & 2,2 \\
Sesak napas & 4 & 2,2 \\
Tersedak & 3 & 1,7 \\
Keluar cairan dari telinga & 2 & 1,1 \\
Bintik kemerahan di kulit & 2 & 1,1 \\
Pemeriksaan Fisik & & \\
Suhu (rerata) & 37,6 & - \\
Nafas Cuping Hidung & 165 & 92,7 \\
Retraksi Dinding Dada & 153 & 86 \\
Ronkhi & 163 & 91,6 \\
Wheezing & 26 & 14,6 \\
\hline
\end{tabular}

Tabel 3 memaparkan gejala klinis pneumonia pada anak. Gejala klinis yang paling banyak ditemukan pada pasien pneumonia anak yang dirawat yaitu demam $92,7 \%$ dengan suhu rata-rata $37,6^{\circ} \mathrm{C}$, kemudian diikuti batuk $92,1 \%$ dan muntah $39,3 \%$. Hasil penelitian ini berbeda dengan penelitian yang dilakukan di Nigeria, didapatkan 99,8\% anak dengan pneumonia mengalami batuk, lalu diikuti oleh demam $94,4 \%$ dan pilek $40,4 \% .{ }^{25}$ Penelitian yang dilakukan oleh Nurjannah juga menemukan batuk sebagai gejala klinis yang paling banyak dijumpai pada pneumonia anak sebesar $94,4 \% .^{15}$ Perbedaan hasil penelitian yang ditemukan mungkin karena alloanamnesis oleh ibu yang lebih peka terhadap demam yang dialami oleh anaknya dibandingkan batuk.

Pneumonia dapat menyebabkan elastisitas paru berkurang sehingga ventilasi paru menurun. 
Untuk mengkompensasi keadaan ini otot pernapasan dipaksa bekerja lebih keras sehingga kebutuhan oksigen tubuh tetap terpenuhi. ${ }^{26}$

Adanya napas cuping hidung pada 92,7\% anak dan retraksi dinding dada pada $86 \%$ anak dalam penelitian ini membuktikan kerja otot pernapasan yang meningkat

Tabel 4. Frekuensi Pernapasan Anak dengan Pneumonia berdasarkan Kelompok Usia

\begin{tabular}{lcc}
\hline \multicolumn{1}{c}{ Usia } & $\begin{array}{c}\text { Normal } \\
\text { (per menit) }^{\mathbf{1 1}}\end{array}$ & $\begin{array}{c}\text { Frek. Napas } \\
\text { (rerata) (per } \\
\text { menit) }\end{array}$ \\
\hline$<2$ bulan & $<60$ & 65,5 \\
$2-<12$ bulan & $<50$ & 61,1 \\
$12-<60$ bulan & $<40$ & 58,6 \\
$\geq 60$ bulan & $<30$ & 46,1 \\
\hline
\end{tabular}

Gejala yang paling menonjol dari pneumonia pada anak yaitu sesak napas. Tabel 4 memaparkan frekuensi napas anak dengan pneumonia, dan dtemukan rata-rata frekuensi napas anak pada setiap kelompok usia berada diatas frekuensi normal (takipneu). Penelitian lain juga menemukan bahwa rata-rata frekuensi napas anak dengan pneumonia yaitu 60 kali/menit. ${ }^{15}$ Data penelitian menunjukkan bahwa takipneu pada pneumonia mempunyai nilai sensitivitas $74 \%$ dan spesifitas $67 \%$ dibandingkan dengan foto thoraks sebagai baku emas, maka dinyatakan bahwa takipneu dapat digunakan sebagai tanda klinis dalam menegakkan diagnosis pneumonia. $^{27}$

Tabel 5. Pemeriksaan Penunjang

\begin{tabular}{lcc}
\hline & $\mathbf{n}$ & $\%$ \\
\hline Hasil Laboratorium (Leukosit) & 9 & 5 \\
$\quad$ Leukopenia & 112 & 63 \\
Normal & 57 & 32 \\
Leukositosis & 172 & 96,6 \\
\hline Rontgen Thoraks & 7 & 3,9 \\
$\quad$ Infiltrat & 5 & 2,8 \\
Perselubungan & 2 & 1,1 \\
Hilus Melebar & \\
$\quad$ Corakan Vaskular &
\end{tabular}

Pemeriksaan laboratorium yang diteliti berupa jumlah leukosit dan dihitung berdasarkan kelompok usia anak karena setiap kelompok usia anak memiliki batas jumlah leukosit normal yang berbeda. ${ }^{28}$ Peneliti menemukan $63 \%$ pasien pneumonia anak memiliki jumlah leukosit dalam batas normal dan 32\% mengalami leukositosis. Hal ini berbeda dengan penelitian di Denpasar yang menemukan jumlah leukosit $>15 \times 10^{9} / \mathrm{L}$ pada $72 \%$ anak dengan pneumonia, dan bakteri merupakan penyebab paling banyak. ${ }^{29}$ Pasien pneumonia anak yang tidak diobati akan mengalami peningkatan leukosit pada hari kedua, sedangkan pada penelitian ini leukosit dihitung saat hari pertama anak dirawat di rumah sakit sehingga jumlah leukosit masih dalam batas normal. $^{29}$

Pemeriksaan foto rontgen thoraks perlu dilakukan untuk menunjang diagnosis, disamping untuk melihat luasnya kelainan patologi yang lebih akurat serta kemungkinan adanya komplikasi seperti pneumothoraks.Infiltrat tersebar sering dijumpai, terutama pada pasien bayi. Hal ini sesuai dengan hasil penelitian yang didapatkan yaitu ditemukan gambaran infitrat pada 96,6\% pasien pneumonia anak yang dirawat. Penelitian yang dilakukan oleh Eldrian juga menemukan gambaran foto rontgen thoraks anak dengan pneumonia yang paling sering yaitu infiltrat $73,21 \%{ }^{18}$ Berbeda dengan pemeriksaan laboratorium jumlah leukosit, pemeriksaan radiologis tidak dapat menunjukkan perbedaan nyata antara infeksi virus dengan bakteri. Seringkali panas dan takipneu sudah timbul sebelum terlihat perubahan pada foto rontgen thoraks. Foto rontgen thoraks umumnya akan kembali normal setelah 3-4 minggu. ${ }^{30}$

Tabel 6. Penyakit Penyerta pada Pneumonia Anak

\begin{tabular}{lcc}
\hline \multicolumn{1}{c}{ Penyakit penyerta } & $\mathbf{n}$ & $\%$ \\
\hline Anemia & 55 & 30,9 \\
Penyakit Jantung Bawaan & 20 & 11,2 \\
Diare & 15 & 8,4 \\
Kandidiasis Oral & 13 & 7,3 \\
Asma Bronkial & 13 & 7,3 \\
Bronkiolitis & 7 & 3,9 \\
Tonsilofaringitis Akut & 7 & 3,9 \\
Sindrom Down & 7 & 3,9 \\
Hipotiroid Kongenital & 7 & 3,9 \\
Hernia Umbilikalis & 4 & 2,2 \\
Kejang Demam & 3 & 1,7 \\
Trakeomalasia Kongenital & 3 & 1,7 \\
Morbili & 2 & 1,1 \\
\hline
\end{tabular}


Tabel 6 memperlihatkan penyakit penyerta yang dimiliki oleh $70,2 \%$ anak dengan pneumonia yang dirawat inap. Anemia merupakan penyakit penyerta yang paling dominan pada pasien pneumonia anak sebesar $30,9 \%$, biasanya anemia yang diakibatkan oleh kekurangan zat besi.

Baskaran dkk dalam sebuah studi menemukan bahwa 83\% dari 43 anak-anak dengan pneumonia antara 3-5 tahun memiliki hemoglobin kurang dari $11 \mathrm{~g} / \mathrm{dL}$. Penelitian prospektif lainnya menyebutkan bahwa anemia pada anak merupakan faktor risiko terjadinya infeksi respiratorik akut bawah (IRA-B), kejadiannya 5,75 kali lebih besar dari pada kelompok tanpa anemia. ${ }^{31}$ Risiko kekerapan infeksi pada anak balita, khususnya infeksi respiratorik, diyakini ada hubungan dengan anemia defisiensi besi, namun beberapa penelitian belum mendapatkan bukti yang bermakna. Meskipun demikian, data epidemiologis mengenai efek suplementasi besi terhadap insiden IRA-B belum cukup bermakna. Penelitian terbaru di Nepal melaporkan bahwa suplementasi besi bersama asam folat dapat mengurangi insiden IRA-B secara bermakna, kemungkinan besar berkaitan dengan perbaikan fungsi imunitas. ${ }^{32}$

Penyakit jantung bawaan juga menyertai pneumonia pada anak sebanyak 11,2\%. Pada penelitian yang dilakukan oleh Sadoh di Nigeria didapatkan $11,57 \%$ anak dengan pneumonia mengalami Congenital Heart Disease (CHD), 50\% diantaranya merupakan Ventrical Septal Defect (VSD). Anak dengan CHD seperti VSD, Atrial Septal Defect (ASD) dan Patent Ductus Arteriosus (PDA) akan mengalami peningkatan aliran darah ke paru sehingga lebih tinggi risiko timbulnya pneumonia. ${ }^{33}$

Terdapat 7,3\% anak dengan pneumonia yang disertai dengan asma brokial. Asma bronkial adalah penyakit yang mendasari pneumonia berulang pada anak. Banyak anak dengan pneumonia berulang yang terbukti memiliki asma yang tidak terdiagnosis. ${ }^{34} \mathrm{Hal}$ ini disebabkan oleh karena anak dengan riwayat asma memiliki risiko saluran pernapasan yang cacat, integritas lendir dan silia terganggu, serta terdapat penurunan imunitas humoral atau seluler, lokal maupun sistemik. ${ }^{7}$

Pada penelitian ini terdapat $3,9 \%$ pasien anak dengan pneumonia yang disertai dengan Sindrom Down. Pasien dengan sindrom Down cenderung memiliki defisiensi imun sehingga sering mengalami pneumonia. Selain itu, seringnya terjadi infeksi saluran napas pada anak dengan Sindrom Down dikarenakan fungsi dan struktur sistem pernapasan yang abnormal, seperti diameter anteroposterior nasofaring yang sempit mengakibatkan terhambatnya drainase yang adekuat, pembentukan sinus dan mukosa hidung yang tidak baik, serta menurunnya aktivitas silia untuk menjaga mukosa hidung agar tetap bersih. ${ }^{35}$

Tabel 7. Komplikasi pada Pasien Pneumonia Anak

\begin{tabular}{lcc}
\hline \multicolumn{1}{c}{ Komplikasi } & $\mathbf{n}$ & $\%$ \\
\hline Gangguan Keseimbangan Asam & 86 & 48,3 \\
Basa & & \\
Syok septik & 6 & 3,4 \\
Septis & 5 & 2,8 \\
Gagal Napas & 3 & 1,7 \\
Otitis Media & 2 & 1,1 \\
Meningitis & 2 & 1,1 \\
Empiema & 1 & 0,6 \\
Tidak ada komplikasi & 87 & 48,9 \\
\hline
\end{tabular}

Tabel 7 memperlihatkan komplikasi yang sering muncul pada pasien anak dengan pneumonia yaitu gangguan asam basa, diantaranya yaitu asidosis metabolik $34,8 \%$ dan alkalosis respiratorik $11,8 \%$, diikuti dengan syok septik $3,4 \%$ dan septis $2,8 \%$. Pada pneumonia berat, anak akan mengalami hipoksia sehingga kekurangan basa bikarbonat ( $\mathrm{HCO}$ ) yang mengakibatkan turunnya $\mathrm{pH}$ darah dibawah 7 dan terjadi hiperventilasi sebagai mekanisme kompensasi tubuh, keadaan ini disebut dengan asidosis metabolik.. Kehilangan karbondioksida berlebihan dari paru pada keadaan produksi normal akan mengakibatkan penurunan $\mathrm{PCO} 2$ dan peningkatan $\mathrm{pH}$ sehingga menimbulkan alkalosis respiratorik. ${ }^{36}$ 


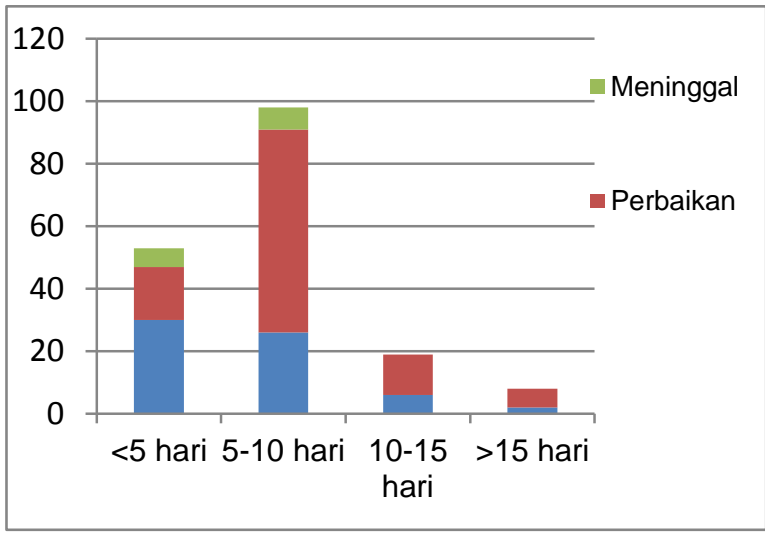

Gambar 1. Grafik Distribusi Frekuensi Pasien Pneumonia Anak berdasarkan Lama Rawatan

Gambar 1 mempelihatkan lama rawatan pasien pneumonia anak. Pada penelitian ini didapatkanhasil lama rawatan terbanyak yaitu 5-10 hari sebesar 55\%, yang mana Suharjono ditahun 2009, Nurjannah pada tahun 2010, dan Kurniawan di tahun 2012 juga mendapatkan hasil yang sama. ${ }^{15,17,19}$ Lama rawatan tergantung pada status gizi, berat penyakit serta penyakit penyertanya. ${ }^{19}$ Selain itu, terdapat beberapa faktor lain yang dapat memperpanjang lama rawatan pasien pneumonia anak yaitu ASI tidak ekslusif, hunian rumah yang padat, dan hasil rontgen thoraks yang abnormal. ${ }^{37}$

Tabel 8.Keberhasilan Terapi pada Pasien Pneumonia Anak

\begin{tabular}{lcc}
\hline \multicolumn{1}{c}{ Keberhasilan Terapi } & $\mathbf{n}$ & $\%$ \\
\hline Sembuh & 101 & 56,7 \\
Belum Sembuh & 64 & 36 \\
Meninggal & 13 & 7,3 \\
\hline Jumlah & 178 & 100 \\
\hline
\end{tabular}

Tabel 8 memaparkan outcome pasien pneumonia anak dan didapatkan outcometerbanyak yaitu sembuh atau perbaikan sebesar 56,7\%. Sebanyak $36 \%$ anak dibawa pulang oleh orangtuanya sebelum kondisi anak memungkinkan untuk pulang, sebagian besar karena masalah biaya.

Pada penelitian ini ditemukan 7,3\% anak pasien pneumonia meninggal dunia, 78\% diantaranya merupakan anak kategori usia $2 \quad-\quad<12$ bulan. Penelitian yang dilakukan sebelumnya oleh Febriane Eldrian mendapatkan bahwa 8,04\% anak meninggal dunia. ${ }^{18}$ Hal ini membuktikan bahwa angka mortalitas anak di Bagian Anak RSUP M.Djamil mulai berkurang karena terapi antibotik yang diberikan adekuat sehingga banyak anak yang pulang dengan perbaikan. Penelitian Suharjono di Surabaya pada tahun 2011 menunjukkan angka kematian pasien pneumonia anak sebesar 2,4\%. ${ }^{17}$ Penelitian yang dilakukan di Nigeria mendapatkan hasil $9 \%$ anak dengan pneumonia meninggal dunia. ${ }^{25}$

\section{KESIMPULAN}

Pasien pneumonia anak paling banyak ditemukan pada kelompok usia $2-<12$ bulan, lebih banyak pada anak laki-laki dari pada anak perempuan dengan angka perbandingan 1,25:1. Pneumonia banyak ditemukan pada anak dengan status gizi kurang dan status imunisasi yang belum lengkap.

Keluhan utama pasien pneumonia adalah sesak napas, dengan onset sesak napas kurang dari 24 jam. Gejala klinis pasien pneumonia anak yaitu demam, batuk dan muntah, dengan hasil pemeriksaan fisik ditemukan suhu rata-rata $37,6^{\circ} \mathrm{C}$, takipneu, takikardi, nafas cuping hidung, retraksi dinding dada, ronkhi dan wheezing. Pada pemeriksaan penunjang ditemukan hasil laboratorium jumlah leukosit dalam batas normal dan gambaran rontgen tersering adalah gambaran infiltrat.

Penyakit penyerta pada pasien pneumonia anak yang paling sering adalah anemia.Komplikasi pneumonia yang paling sering muncul yaitu gangguan keseimbangan asam basa. Lama perawatan pasien pneumonia anak yaitu 5-10 hari dan hasil pengobatan (outcome) keluar dengan perbaikan.

\section{UCAPAN TERIMA KASIH}

Ucapan terima kasih kepada dr. Finny Fitry Yani, $\operatorname{SpA}(\mathrm{K})$ dan dr. Yuniar Lestari, M.Kes yang telah banyak mengorbankan waktu, pikiran, dan tenaga dalam memberikan arahan dan masukan untuk penelitian ini.

\section{DAFTAR PUSTAKA}

1. Dahlan Z. Pneumonia. Dalam: Sudoyo AW, Setiyohadi B,Alwi I, Simadibrata M, Setiati S, editor. Buku Ajar IImu Penyakit Dalam Jilid III. 
Edisi V. Jakarta: Interna Publishing; 2009 196.

2. Sectish T, Prober CG. Pneumonia. In: Kliegman RM, Behrman RE, Jenson HB, Stanton BF, eds. Nelson Textbook of Pediatrics. $18^{\text {th }}$ ed. Philadelphia: Saunders Elsevier; 2008. 1795 - 9.

3. PDPI. Pneumonia Komuniti Pedoman Diagnosis \& Penatalaksanaan Di Indonesia [serial online]. 2003. (diunduh 21 Maret 2014). Tersedia dari: URL: HYPERLINK http://klikpdpi.com/konsensus/konsensuspneumoniakom/pnkomuniti.pdf.

4. Amorim PG, Morcillo AM, Tresoldi AT, Fraga AMA, Peirera MR, Baracat ECM. Factors associated with complications of communityacquired pneumonia in preschool children. $J$ Bras Pneumol. 2012: 38 (5):614-21.

5. The United Nations Children's Fund (UNICEF), World Health Organization (WHO). Pneumonia the forgotten killer of children [serial online]. 2006. (diunduh 7 Juni 2013). Tersedia dari: URL: HYPERLINK http://unicef.org/publications/index 35626.ht $\underline{\mathrm{ml}}$.

6. Price SA, Wilson LM.. Patofisiologi: Konsep Klinis Proses-proses Penyakit Edisi 6. Jakarta: EGC; 2006.

7. Sunyataningkamto, Iskandar Z, Alan RT, Budiman I, Surjono A, Wibowo T, dkk. The role of indoor air pollution and other factors in the incidence of pneumonia in under-five children. Paediatrica Indonesiana. 2004; 44 $(1-2): 25-9$.

8. Hartati S. Analisis Faktor Risiko yang Berhubungan dengan Kejadian Pneumonia pada Anak Balita di RSUD Pasar Kebo Jakarta. Tesis. Depok. Program Magister IImu Keperawatan Universitas Indonesia. 2011.

9. Herman. Faktor-faktor yang berhubungan dengan kejadian pneumonia pada anak balita di kab. Ogan Komering Ilir Sumatera Selatan. Tesis. Jakarta: Fakultas Kesehatan
Masyarakat Universitas Indonesia. 2002.

10. Soewignjo S, Gessner BD, Sutanto A, Steinhoff M, Prijanto M, Nelson C, et al.. Streptococcus pneumonia Nasopharyngeal Carriage Prevalence, Serotype Distribution, and Resistance Patterns among Children on Lombok Island, Indonesia.Clinical Infection Disease. 2001; 32:1039-43.

11. World Health Organization (WHO). Pneumonia [serial online]. April 2013. (diunduh 3 Mei 2013). Tersedia dari: URL: HYPERLINK http://who.int/mediacentre/ factsheets/fs331/en/.

12. Durbin WJ, Stille C.. Pneumonia.Pediatric in Review. 2008; 29 (5):147 - 60.

13. Yuwono, Aji T. Faktor-faktor lingkungan fisik rumah yang berhubungan dengan kejadian pneumonia pada anak balita di wilayah kerja puskesmas Kawunganten Kabupaten Cilacap. Tesis. Semarang. Program Pasca Sarjana Universitas Diponegoro Semarang. 2008.

14. Dinas Kesehatan Provinsi Sumatera Barat. Profil Kesehatan Provinsi Sumatera Barat Tahun 2012. Padang: Dinas Kesehatan; 2013.

15. Nurjannah, Sovira N, Anwar S. Profil Pneumonia pada Anak di RSUD Dr. Zainoel Abidin, Studi Retrospektif. Sari Pediatri. 2012; 13 (5):32-28.

16. Mauli S. Karakteristik Balita Yang Menderita Pneumonia Di Wilayah Kerja Puskesmas Kota Sigli Kabupaten Pidie Tahun 2013. Jurnal Karya Tulis IImiah. Banda Aceh:2013

17. Suharjono, Yuniati T, Sumarno, Semedi J. Studi penggunaan antibiotika pada penderita rawat inap pneumonia (penelitian di sub departemen anak rumkital dr. Ramelan surabaya). Majalah IImu Kefarmasian. 2009; VI (3):142-55.

18. Eldrian F. Gambaran Pneumonia Anak yang Dirawat di Perjan RS DR. M. Djamil Padang. Skripsi. Padang. Program S1 Sarjana Kesehatan Uiversitas Andalas. 2005. 
19. Kurniawan $Y$, Indriyani SAK. Karakteristik Pasien Pneumonia di Ruang Rawat Inap Anak Rumah Sakit Umum Provinsi Nusa Tenggara Barat. CDK-191. 2012;39(3):196-7.

20. Saputra W, Nurrizka RH. Faktor Demografi Dan Risiko Gizi Buruk Dan Gizi Kurang. Makara, Kesehatan.2012;16(2):95-101.

21. KartasasmitaCB. Pneumonia Pembunuh Balita. Dalam: Buletin Jendela Epidemiologi. 2010;3(3): 22-6.

22. Misnadiarly. Penyakit Infeksi Saluran Napas Pneumonia. Ed 1. Jakarta: Pustaka Obor Populer; 2008. 26-49.

23. Annah I, Nawi R, Ansar J. Faktor Risiko Kejadian Pneumonia Anak Umur 6-59 Bulan di RSUD Salewangan Maros Tahun 2012.Makassar: FKM UNHAS. 2012.

24. Onyago D, Kikuvi G, Amukoye E, Omolo J. Risk factors of severe pneumonia among children aged 2-59 months in western Kenya: a case control study. Pan African Medical Journal, 2012;13(45):1-13.

25. Mustapha MG, Ashir GM, Alhaji MA, Rabasa Al, Ibrahim BA, Mustapha Z. Presentation, complications and management outcome of community acquired pneumonia in hospitalized children in Maiduguri, Nigeria.Niger J Paed, 2013;40 (1):30-3.

26. Muttaqin, A. Buku Ajar Asuhan Keperawatan Klien dengan Gangguan Sistem Pernapasan. Jakarta: Salemba Medika. 2008:41.

27. Palafox M, Guiscrafe $H$, Reyes $H$, Munoz O, Martinez H. Diagnostic value of tachypnoea in pneumonia defined radiologically. Arch Dis Child.2000;82:41-5.

28. Ohls RK, Christensen RD.. Development of the hematopoietic system. In: Kliegman, Behrman, Jenson, Staton eds. Nelson Textbook of Pediatrics. 18th ed.
Philadelphia: Saunders Elsevier. 2007:2003.

29. Subanada IB, Puriniti NS. Faktor-faktor yang Berhubungan dengan Pneumonia Bakteri pada Anak. Sari Pediatri. 2010;12 (3):184-9.

30. Asih R, Setiawati L, Makmuri. Kuliah Pneumonia dalam Continuing Education IImu Kesehatan Anak XXXVI. Surabaya;2006.

31. Ramakrishnan K, Harish PS. Hemoglobin Level as a Risk Factor for Lower Respiratory Tract Infections. Indian Journal of Pediatrics.2006;73:881-3.

32. Wirawan IKA, Ariawati K, Subanada ID. Prevalence and Hematology Profile of Anemia in Patients With Acute Lower Respiratory Infection. Medicina. 2012;(43): 89-94.

33. Sadoh WE, Osarogiagbon WO. Underlying congenital heart disease in Nigerian children with Pneumonia. African Health Science. 2013;3(3):607-12.

34. Ozdemir O, Sari S, Bakirtas A, Zorlu P, Ertan U.Underlying diseases of recurrent pneumonia in Turkish children. Turk $\mathrm{J}$ Med Sci.2010;40(1):25-30.

35. Perrez JAH, Guerra JSH. Communityacquired pneumonia in adults with Down syndrome. Three clinical cases and a review of the literature. Rev Med Int Sindr Down. 2010;14(2):25-30.

36. Adelman RD, Solhaug MJ.. Patofisiologi Cairan Tubuh dan Terapi Cairan. Dalam: Behrman, Kliegman, Arvin. Wahab AS (ed). IImu Kesehatan Anak Nelson (1) Ed 15. Philladelphia: EGC; 2000. 250-8.

37. Tiewsoh K, Lodha R, Pandey RM, Broor S, Kalaivani M, Kabra SK. Factors determining the outcome of children hospitalized with severe pneumonia. BMC Pediatric.2009; 9 (15):1-8. 